\title{
Emergence, growth, and flowering of castor beans as a function of the cationic composition of irrigation water
}

\section{Emergência, crescimento e floração da mamoneira em função da composição catiônica da água de irrigação}

\author{
Geovani Soares de Lima ${ }^{1 *}$; Hans Raj Gheyi²; Reginaldo Gomes Nobre”; \\ Diego Azevedo Xavier ${ }^{4}$; Lauriane Almeida dos Anjos Soares ${ }^{5}$; \\ Lourival Ferreira Cavalcante ${ }^{6}$; João Batista dos Santos ${ }^{7}$
}

\begin{abstract}
The use of saline water in agriculture has contributed to the expansion of irrigated areas, especially in arid and semiarid regions, where water deficits occur during various months of the year. In this context, this study aimed to evaluate the emergence, growth, and flowering of the castor bean cultivar "BRS Energia" as a function of the cationic composition of irrigation water, including water containing single and multiple types of cations. The experiment was carried out in a greenhouse in the municipality of Campina Grande-PB, Brazil using drainage lysimeters filled with a sandy loam Ultisol. The experiment was set in a randomized block design, with four replicates each of six water salinity treatments: Control; $\mathrm{Na}^{+} ; \mathrm{Ca}^{2+} ; \mathrm{Na}^{+}+\mathrm{Ca}^{2+} ; \mathrm{K}^{+}$; and $\mathrm{Na}^{+}+\mathrm{Ca}^{2+}+\mathrm{Mg}^{2}$, totaling 24 experimental plots, each consisting of five plants. Plants in the control treatment were subjected to irrigation using water having low electrical conductivity $\left(\mathrm{ECW}=0.6 \mathrm{dS} \mathrm{m}^{-1}\right)$, while the plants receiving other treatments were irrigated using 4.5 $\mathrm{dS} \mathrm{m}{ }^{-1}$ water containing different ions. Emergence and growth were more affected by the ECw than by the cationic composition of the irrigation water. The order of the cations in the irrigation water, in terms of negative effects, was $\mathrm{Na}^{+}>\mathrm{Na}^{+}+\mathrm{Ca}^{+}>\mathrm{Ca}^{2+}>\mathrm{Na}^{+}+\mathrm{Ca}^{2+}+\mathrm{Mg}^{2+}>\mathrm{K}^{+}$. The cationic composition of the irrigation water influenced the time interval for inflorescence development and the opening of flower buds of the castor bean cultivar "BRS Energia", and the most pronounced effects were observed in plants irrigated with calcic water.
\end{abstract}

Key words: Ricinus communis L. Water quality. Saline stress.

\section{Resumo}

A utilização de águas salinas na agricultura tem contribuído para a expansão de áreas irrigadas, principalmente em regiões áridas e semiáridas, onde ocorre déficit hídrico durante vários meses do

\footnotetext{
${ }^{1}$ Bolsista do Programa Nacional de Pós-Doutorado, PNPD/CAPES, Universidade Federal de Campina Grande, UFCG, Centro de Tecnologia e Recursos Naturais, Campina Grande, PB, Brasil. E-mail: geovanisoareslima@gmail.com

${ }^{2}$ Prof. Visitante Nacional Sênior, CAPES, Universidade Federal do Recôncavo da Bahia, UFRB, Cruz das Almas, Bahia, Brasil. E-mail: hans@pq.cnpq.br

${ }^{3}$ Prof.,Unidade Acadêmica de Ciências Agrárias, UFCG, Pombal, PB, Brasil. E-mail: rgomesnobre@yahoo.com.br

${ }^{4}$ Discente do Curso de Mestrado em Engenharia Agrícola, UFCG, Centro de Tecnologia e Recursos Naturais Campina Grande, PB, Brasil. E-mail: daxengagricola@gmail.com

${ }_{5}^{5}$ Discente do Curso de Doutorado em Engenharia Agrícola, UFCG, Centro de Tecnologia e Recursos Naturais Campina Grande, PB, Brasil. E-mail: laurispo.agronomia@gmail.com

${ }^{6}$ Prof., Dept ${ }^{\text {}}$ de Solos e Engenharia Rural, Universidade Federal da Paraíba, UFPB, Areia, PB, Brasil. E-mail: lofeca@cca.ufpb.br

${ }^{7}$ Bolsista de Pós-Doutorado Júnior, CNPq, UFCG, Centro de Tecnologia e Recursos Naturais, Campina Grande, PB, Brasil. E-mail: agrosantos@hotmail.com

* Author for correspondence
} 
ano. Neste contexto propôs-se, no presente trabalho, avaliar a emergência o crescimento e a floração da mamoneira cv. 'BRS Energia' em função da composição catiônica, isolada ou mista, da água de irrigação. $\mathrm{O}$ estudo foi conduzido em lisímetros de drenagem em condições de casa de vegetação, no Argissolo Acinzentado Eutrófico de textura franco-arenosa, no município de Campina Grande, PB. Usou-se o delineamento de blocos ao acaso testando-se seis tratamentos de salinidade da água (Testemunha; $\mathrm{Na}^{+} ; \mathrm{Ca}^{2+} ; \mathrm{Na}^{+}+\mathrm{Ca}^{2+} ; \mathrm{K}^{+}$e $\mathrm{Na}^{+}+\mathrm{Ca}^{2+}+\mathrm{Mg}^{2+}$ ) e quatro repetições, totalizando 24 parcelas experimentais, cada uma composta de cinco plantas, sendo que as plantas sob o tratamento testemunha foram submetidas à irrigação com água de baixa condutividade elétrica $\left(\mathrm{CEa}=0,6 \mathrm{dS} \mathrm{m}^{-1}\right)$ e os demais tratamentos foram irrigadas com CEa de $4,5 \mathrm{dS} \mathrm{m}^{-1}$ preparada com diferentes íons. A emergência e o crescimento foram mais afetados pela CEa quando comparado com a composição catiônica da água de irrigação; o efeito negativo do tipo de cátion presente na água de irrigação obedeceu à seguinte ordem: $\mathrm{Na}^{+}>\mathrm{Na}^{+}+\mathrm{Ca}^{+}>\mathrm{Ca}^{2+}>\mathrm{Na}^{+}+\mathrm{Ca}^{2+}+\mathrm{Mg}^{2+}>\mathrm{K}^{+}$; a composição catiônica da água de irrigação influenciou o intervalo de tempo para a desenvolvimento da inflorescência e a antese do botão floral da mamoneira cv. 'BRS Energia', sendo os efeitos mais acentuados observados nas plantas irrigadas com águas de composição cálcica.

Palavras-chave: Ricinus communis L. Qualidade de água. Estresse salino.

\section{Introduction}

The castor bean plant, an oil seed crop from the Euphorbiaceae family that possibly originated in Ethiopia, has great social and economic importance (SILVA et al., 2007) because of the multiple uses of the oil extracted from its seeds, including in the industrial sector, where it is widely used in the production of paints, cosmetics, soaps, varnishes, adhesives, fungicides, insecticides, and even prosthetics and implants. In addition, during the industrial processing of the oil, a byproduct (cake) is generated having great potential as a fertilizer (RODRIGUES et al., 2009).

Areas where castor beans are cultivated, especially in the semiarid region of northeast Brazil, are subject to climatic variation, and high temperatures, low rainfall, irregular rainfall distribution, and high evapotranspiration rates are common for most of the year, resulting in a shortage of surface water; thus, irrigation is important to guarantee water supply during the periods with the highest demands (NOBRE et al., 2011).

In addition to climatic conditions, the sources of water for irrigation in this region alternate geographically and seasonally, from temporary rivers to shallow wells. Further, water sources with high salt concentrations are quite common (SILVA et al., 2005; BEZERRA et al., 2010).
Silva Júnior et al. (1999) evaluated the variation in the ionic composition of water from the crystalline region in the Northeast of Brazil (the states of Paraíba, Rio Grande do Norte, and Ceará) and observed a predominance of sodium-chloride water with certain variation regardless of the salinity level, site, or source. Costa and Gheyi (1984), studying the variation in the quality of irrigation water in the municipalities of the microregion of Catolé do Rocha-PB, using water from various sources (shallow wells and weirs) and that collected during rainy and dry periods, observed that $\mathrm{Na}^{+}$generally is present in abundance compared to $\mathrm{Ca}^{2+}$ and $\mathrm{Mg}^{2+}$ in water collected during dry periods; however, in the rainy period, greater abundances of $\mathrm{Ca}^{2+}$ and $\mathrm{Mg}^{2+}$ than $\mathrm{Na}^{+}$were observed, especially in low-salinity water $\left(\mathrm{ECw}<750 \mu \mathrm{S} \mathrm{cm}^{-1}\right)$.

Some authors consider the castor bean crop to be moderately sensitive to salinity (AYERS; WESTCOT, 1999; CAVALCANTI et al., 2005; BABITA et al., 2010; NOBRE et al., 2013; SANTOS et al., 2013); however, the tolerance varies among cultivars of the species and is influenced by other factors, such as salt type and concentration, exposure time, phenological stage, edaphoclimatic factors, and the interaction between these factors (ASHRAF; HARRIS, 2004). 
Thus, many researchers have observed negative effects of salinity on castor bean plants (CAMPOS et al., 2009; SOARES et al., 2012; ALVES et al., 2012; NOBRE et al., 2013; SANTOS et al., 2013; LIMA et al., 2014); however, these studies are restricted to the effects of different salinity levels, so there is a need for further studies, especially in order to verify the effects of differences in the cationic composition of irrigation water on the castor bean cultivar 'BRS Energia'.

In this context, this study aimed to evaluate the emergence, growth, and flowering of the castor bean cultivar 'BRS Energia' as a function of the cationic composition of the irrigation water, including with single and multiple types of cations.

\section{Material and Methods}

The experiment was carried out from November 2013 to February 2014 using drainage lysimeters under greenhouse conditions at the Center of Technology and Natural Resources of the Federal University of Campina Grande (CTRN/UFCG), located in the municipality of Campina Grande-PB,

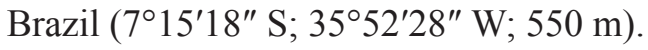

The treatments comprised six types of salinity $\left(\mathrm{S}_{1}-\right.$ Control; $\mathrm{S}_{2}-\mathrm{Na}^{+} ; \mathrm{S}_{3}-\mathrm{Ca}^{2+} ; \mathrm{S}_{4}-\mathrm{Na}^{+}+\mathrm{Ca}^{2+}$; $\mathrm{S}_{5}-\mathrm{K}^{+}$; and $\mathrm{S}_{6}-\mathrm{Na}^{+}+\mathrm{Ca}^{2+}+\mathrm{Mg}^{2+}$ ), with a $1: 1$ $\mathrm{Na}^{+}+\mathrm{Ca}^{2+}$ ratio in $\mathrm{S}_{4}$ and a $7: 2: 1 \mathrm{Na}^{+}+\mathrm{Ca}^{2+}+\mathrm{Mg}^{2+}$ ratio in $\mathrm{S}_{6}$. Plants in the control treatment $\left(\mathrm{S}_{1}\right)$ were irrigated with locally supplied water having an electrical conductivity (ECw) of $0.6 \mathrm{dS} \mathrm{m}{ }^{-1}$, while the other treatments were irrigated using water with an ECw of $4.5 \mathrm{dS} \mathrm{m}^{-1}$, prepared with different cations in chloride form, according to the characteristics shown in Table 1. The experiment was set in a randomized block design with six treatments and four replicates, totaling 24 experimental plots, each with five plants for evaluation.

The castor bean cultivar 'BRS Energia' was selected for this experiment because of its vigorous genetic material, fast growth (cycle of 120 to 150 days), short size, semi-dehiscent fruits, mean oil content in the seeds of $48 \%$, and average yield of $1,800 \mathrm{~kg} \mathrm{ha}^{-1}$ (SILVA et al., 2009).

Table 1. Chemical characteristics of the water used in the experiment.

\begin{tabular}{cccccccccc}
\hline \multirow{2}{*}{ Treatment } & $\begin{array}{c}\mathrm{ECw} \\
\mathrm{dS} \mathrm{m}\end{array}$ & $\mathrm{pH}$ & $\mathrm{Ca}^{2+}$ & $\mathrm{Mg}^{2+}$ & $\mathrm{Na}^{+}$ & $\mathrm{K}^{+}$ & $\mathrm{HCO}_{3}^{-}$ & $\mathrm{Cl}^{-}$ & $\begin{array}{c}\text { SAR } \\
\left(\mathrm{mmol} \mathrm{L}^{-1}\right)^{0,5}\end{array}$ \\
\hline $\mathrm{Control}^{n n n n n n y y y y n}$ & 0.60 & 7.23 & 1.19 & 1.58 & 2.83 & 0.10 & 1.45 & 4.22 & 2.41 \\
$\mathrm{Na}^{+}$ & 4.50 & 7.40 & 6.12 & 3.50 & 33.10 & 0.16 & 6.40 & 57.00 & 15.11 \\
$\mathrm{Ca}^{2+}$ & 4.50 & 7.35 & 31.37 & 15.25 & 5.22 & 0.18 & 3.40 & 38.75 & 1.08 \\
$\mathrm{Na}^{+}+\mathrm{Ca}^{2+}$ & 4.50 & 7.38 & 17.75 & 5.00 & 20.22 & 0.16 & 3.80 & 41.25 & 6.00 \\
$\mathrm{~K}^{+}$ & 4.50 & 7.75 & 1.75 & 6.87 & 5.59 & 22.28 & 5.00 & 38.00 & 1.29 \\
$\mathrm{Na}^{+}+\mathrm{Ca}^{2+}+\mathrm{Mg}^{2+}$ & 4.50 & 7.40 & 11.00 & 9.00 & 25.74 & 0.14 & 2.60 & 39.75 & 8.14 \\
\hline
\end{tabular}

$\mathrm{ECw}$ - electrical conductivity of water; $\mathrm{SAR}$ - sodium adsorption ratio; $\mathrm{CO}_{3}{ }^{2-}-$ absent.

Plants were cultivated in $100-\mathrm{L}$ drainage lysimeters (height $=50 \mathrm{~cm}$, bottom diameter $=$ $30 \mathrm{~cm}$, and top opening $=33 \mathrm{~cm}$ ) perforated at the bottom, where two drains $(\varnothing=4 \mathrm{~mm})$ were installed to allow the removal of excess water. The tip of the drain inside each lysimeter was covered with a nonwoven geotextile (Bidim OP 30) to avoid obstruction with soil material, and a plastic container was placed under each drain to collect the drained water and estimate plant water consumption.

The lysimeters were filled with a layer of $2 \mathrm{~kg}$ of crushed stone (No. 0), followed by $54 \mathrm{~kg}$ of soil material (clod-free and properly homogenized) and $76 \mathrm{~kg}$ of the same soil mixed with $1.70 \mathrm{~kg}$ of 
earthworm humus in order to achieve $1 \%$ organic matter in the soil based on the total weight. The first $10 \mathrm{~cm}$ on the upper part of the lysimeter remained empty to facilitate irrigation. The soil used in the study was collected from the $0-30 \mathrm{~cm}$ layer (A horizon) of an Ultisol in the district of São
José da Mata (Campina Grande-PB). Before the experiment, the soil was sampled and the chemical and hydro-physical characteristics (Table 2) were determined at the Irrigation and Salinity Laboratory of the CTRN/UFCG according to the methodology proposed by Claessen (1997).

Table 2. Chemical and hydro-physical characteristics of the soil used in the experiment before treatments.

\begin{tabular}{|c|c|c|c|c|c|c|c|c|}
\hline \multicolumn{9}{|c|}{ Chemical characteristics } \\
\hline \multirow[b]{2}{*}{$\mathrm{pH}_{\mathrm{ps}}$} & \multirow{2}{*}{$\begin{array}{c}\mathrm{OM} \\
\text { dag kg-1 }\end{array}$} & \multirow{2}{*}{$\begin{array}{c}\mathrm{P} \\
\left(\mathrm{mg} \mathrm{kg}^{-1}\right)\end{array}$} & $\mathrm{K}^{+}$ & $\mathrm{Na}^{+}$ & $\mathrm{Ca}^{2+}$ & $\mathrm{Mg}^{2+}$ & $\mathrm{Al}^{3+}$ & $\mathrm{H}^{+}$ \\
\hline & & & \multicolumn{6}{|c|}{ 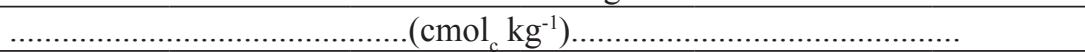 } \\
\hline 5.10 & 0.34 & 20.09 & 0.07 & 0.05 & 0.40 & 1.30 & 0.04 & 1.74 \\
\hline \multicolumn{9}{|c|}{ Physical characteristics } \\
\hline \multicolumn{3}{|c|}{ Size fraction $\left(\mathrm{g} \mathrm{kg}^{-1}\right)$} & \multirow{2}{*}{$\begin{array}{c}\text { Textural } \\
\text { class }\end{array}$} & \multicolumn{2}{|c|}{ Water content $(\mathrm{kPa})$} & \multirow[t]{2}{*}{ AW } & \multirow{2}{*}{$\begin{array}{l}\text { Total porosity } \\
\mathrm{m}^{3} \mathrm{~m}^{-3}\end{array}$} & \multirow{2}{*}{$\begin{array}{c}\text { Density } \\
\left(\mathrm{kg} \mathrm{dm}^{-3}\right)\end{array}$} \\
\hline Sand & Silt & Clay & & $\begin{array}{c}33.42 \\
\ldots \ldots \ldots \ldots \ldots \ldots \\
\end{array}$ & $\begin{array}{c}1519.5 \\
\text { dag kg }^{-1}\end{array}$ & & & \\
\hline 856.10 & 110.70 & 33.20 & SL & 6.72 & 1.62 & 5.10 & 0.49 & 1.54 \\
\hline
\end{tabular}

$\mathrm{pH}_{\mathrm{PS}}-\mathrm{pH}$ of saturated paste; $\mathrm{OM}$ - organic matter: determined by wet digestion Walkley-Black method; $\mathrm{Ca}^{2+}$ and $\mathrm{Mg}^{2+} \mathrm{extracted}^{-}$ with $\mathrm{KCl} 1 \mathrm{~mol} \mathrm{~L}^{-1}$ at $\mathrm{pH} 7.0 ; \mathrm{Na}^{+}$and $\mathrm{K}^{+}$extracted with $\mathrm{NH}_{4} \mathrm{OAc} 1 \mathrm{~mol} \mathrm{~L}^{-1}$ at $\mathrm{pH} 7.0$; $\mathrm{SL}$ - sandy loam; AW - available water.

Based on the chemical analysis of the soil, the acidity was corrected using $49.25 \mathrm{~g}$ of dolomitic limestone in each lysimeter (130 kg of soil), the amount necessary to neutralize $\mathrm{Al}^{3+}$ and raise the contents of $\mathrm{Ca}^{2+}$ and $\mathrm{Mg}^{2+}$ to $70 \%$ base saturation. After liming, the soil had the following chemical characteristics: $\mathrm{Ca}^{2+}=1.14 \mathrm{cmol}_{\mathrm{c}} \mathrm{kg}^{-1} ; \mathrm{Mg}^{2+}=1.36$ $\mathrm{cmol}_{\mathrm{c}} \mathrm{kg}^{-1} ; \mathrm{Na}^{+}=0.30 \mathrm{cmol}_{\mathrm{c}} \mathrm{kg}^{-1} ; \mathrm{K}^{+}=0.14 \mathrm{cmol}_{\mathrm{c}}$ $\mathrm{kg}^{-1} ; \mathrm{H}^{+}=0.11 \mathrm{cmol}_{\mathrm{c}} \mathrm{kg}^{-1} ; \mathrm{Al}^{3+}=0 \mathrm{cmol}_{\mathrm{c}} \mathrm{kg}^{-1}$; cation exchange capacity $(\mathrm{CEC})=3.05 \mathrm{cmol}_{\mathrm{c}} \mathrm{kg}^{-1}$; organic matter $(\mathrm{OM})=1.08 \mathrm{dag} \mathrm{kg}^{-1} ; \mathrm{P}=47.80 \mathrm{mg} \mathrm{kg}^{-1}$; and $\mathrm{pH}$ in water $(1: 2.5)=6.42$.

The water salinity levels were obtained by dissolution of sodium $(\mathrm{NaCl})$, calcium $\left(\mathrm{CaCl}_{2} \cdot 2 \mathrm{H}_{2} \mathrm{O}\right)$, magnesium $\left(\mathrm{MgCl}_{2} \cdot 6 \mathrm{H}_{2} \mathrm{O}\right)$ and potassium $(\mathrm{KCl})$ chlorides in the irrigation water, according to the treatments, using water from the local supply system of Campina Grande-PB. The amounts were determined according to the equation of Richards (1954,) taking into account the relation between $\mathrm{ECW}$ and salt concentration $\left(10 \mathrm{mmol}_{\mathrm{c}} \mathrm{L}^{-1}\right.$ $\left.=1 \mathrm{dS} \mathrm{m}{ }^{-1}\right)$. The salts used $\left(\mathrm{NaCl} ; \mathrm{CaCl}_{2} \cdot 2 \mathrm{H}_{2} \mathrm{O}\right.$; $\mathrm{MgCl}_{2} \cdot 6 \mathrm{H}_{2} \mathrm{O}$; and $\mathrm{KCl}$ ) had purities of $99 \%$. After preparation and $\mathrm{ECw}$ calibration using a portable conductivity meter, the waters were stored in plastic containers and adequately protected to avoid evaporation.

Before seeding, the volume of water necessary to reach field capacity was determined through the capillary saturation method followed by free drainage, and water was applied according to the treatments. After the soil reached field capacity, 10 seeds of the castor bean cultivar 'BRS Energia' were planted equidistantly in each lysimeter in 2-cm-deep holes. Thinning was performed 10 days after seeding (DAS) to leave only one plant per pot.

The soil was kept close to field capacity through daily irrigation by applying water in each lysimeter according to the treatments. The volume applied was determined based on plant water demand, estimated through the water balance: applied water volume minus water volume drained in the previous irrigation, plus the leaching fraction of 0.10 , according to previous studies (NOBRE et al., 2013; LIMA et al., 2014). 
Fertilization was performed for nitrogen, potassium, and phosphorus based on the recommendations of Novais et al. (1991), using 40.62 $\mathrm{g}$ of potassium nitrate and $75 \mathrm{~g}$ of monoammonium phosphate, corresponding to 100,150 , and 300 mg kg-1 of soil of $\mathrm{N}, \mathrm{K}_{2} \mathrm{O}$, and $\mathrm{P}_{2} \mathrm{O}_{5}$, respectively. Fertilizer was application as topdressing in four applications via fertigation at intervals of ten days, with the first applied at 15 DAS. In order to avoid any possible deficiency of micronutrients in the castor bean plants, foliar application with $7 \mathrm{~L}$ of a solution containing $2.5 \mathrm{~g} \mathrm{~L}^{-1}$ of Ubyfol [N (15\%); $\mathrm{P}_{2} \mathrm{O}_{5}$ (15\%); K2 O (15\%); Ca (1\%); Mg (1.4\%); S (2.7\%); $\mathrm{Zn}(0.5 \%)$; B (0.05\%); Fe (0.5\%); Mn (0.05\%); Cu $(0.5 \%)$; and Mo $(0.02 \%)]$ was performed at 30 and 60 DAS.

The phytosanitary management comprised weekly manual weedings, superficial scarification of the soil before each irrigation event, and staking after plants reached the flowering stage, in order to avoid lodging. In addition, $5.4 \mathrm{~g} \mathrm{~L}^{-1}$ of insecticides from the Neonicotinoid chemical group, $7.0 \mathrm{~g} \mathrm{~L}^{-1}$ of fungicide from the triazole chemical group and $3.5 \mathrm{~g} \mathrm{~L}^{-1}$ of acaricides from the abamectin chemical group were applied.

Plant emergence was evaluated until its stabilization through daily records of the number of emerged plants, adopting as a criterion the appearance of the epicotyl on the soil surface. Then, the percent emergence (EP; number of emerged seedlings in relation to the number of planted seeds) was measured. At 13 DAS, the emergence speed index (ESI) was determined according to the methodology described by Vieira and Carvalho (1994), as shown in Eq. 1:

ESI $\left(\right.$ seedlings day $\left.{ }^{-1}\right)=\frac{\sum_{1}}{N_{1}}+\frac{\sum_{2}}{N_{2}}+\cdots+\frac{\sum_{n}}{N_{n}}$

where:

$\Sigma_{1}, \Sigma_{2}, \ldots \Sigma_{\mathrm{n}}$ represent the number of emerged seedlings in the first, second, and last counts, respectively; and
$\mathrm{N}_{1}, \mathrm{~N}_{2}, \ldots \mathrm{N}_{\mathrm{n}}$ represent the number of days from the seeding to the first, second, and last counts, respectively.

The growth of castor beans was determined at 20 and 60 DAS through the measurement of leaf area (LA), plant height $(\mathrm{PH})$, and stem diameter (SD), and the flowering was evaluated at 60 DAS through the determination of the number of days for inflorescence development (NDI) and flower bud opening (NDFO). Plant height was measured as the distance from the plant base to the insertion of the apical meristem. Stem diameter was measured at 5 $\mathrm{cm}$ above the plant base using a digital caliper. Leaf area was obtained by measuring the length of the midrib of all of the leaves in the plants, following the methodology described by Severino et al. (2005), according to Eq. 2:

$$
\mathrm{S}=\mathbf{\Sigma} 0.26622 x \mathrm{P}^{2} .4248
$$

where:

$\mathrm{S}=$ total leaf area per plant $\left(\mathrm{cm}^{2}\right)$;

$\mathrm{P}=$ midrib length $(\mathrm{cm})$.

NDI and NDFO were estimated by daily monitoring for the appearance of inflorescences and flowers.

The obtained data were subjected to analysis of variance through F test; when significant, the data were subjected to a means comparison test for contrasts between the treatment means (Tukey at 0.05 probability level) using the statistical software SISVAR-ESAL. For the comparison of the treatments, the standard error was calculated for each mean. The contrasts were defined as follows: $\hat{\mathrm{y}}_{1}\left(\mathrm{~S}_{1} \mathrm{vs} \mathrm{S}_{2} ; \mathrm{S}_{3} ; \mathrm{S}_{4} ; \mathrm{S}_{5} ; \mathrm{S}_{6}\right) ; \hat{\mathrm{y}}_{2}\left(\mathrm{~S}_{2} \mathrm{vs} \mathrm{S}_{3}\right) ; \hat{y}_{3}\left(\mathrm{~S}_{2} \mathrm{vs} \mathrm{S}_{6}\right)$; $\hat{\mathrm{y}}_{4}\left(\mathrm{~S}_{2}\right.$ vs $\left.\mathrm{S}_{5}\right)$; and $\hat{\mathrm{y}}_{5}\left(\mathrm{~S}_{5}\right.$ vs $\left.\mathrm{S}_{2} ; \mathrm{S}_{3} ; \mathrm{S}_{4} ; \mathrm{S}_{6}\right)$.

\section{Results and Discussion}

According to the summary of the analysis of variance (Table 3 ), the emergence speed index 
(ESI) and the percent emergence (EP) of castor bean seedlings were significantly affected $(p<0.01)$ by the studied types of water salinity. Different results were obtained by Cavalcanti et al. (2005), who studied the effect of water salinity (from 0.7 to $\left.4.7 \mathrm{dS} \mathrm{m} \mathrm{m}^{-1}\right)$, ionic proportions $\left(\mathrm{Na}^{+}+\mathrm{Ca}^{2+}\right)$, and their interaction on the castor bean cultivar "BRS 149 Nordestina". These authors did not observe a significant influence on percent emergence and emergence speed index, which shows that different genotypes from the same species can have different behaviors.

Table 3. Summary of an analysis of variance related to the emergence speed index (ESI) and percent emergence (EP) of castor bean cv. 'BRS Energia' irrigated with water of different types of salinity.

\begin{tabular}{|c|c|c|c|}
\hline \multirow{2}{*}{ SV/Contrasts } & \multirow{2}{*}{ GL } & \multicolumn{2}{|c|}{ Mean square } \\
\hline & & ESI & EP \\
\hline Blocks & 3 & $0.01^{\mathrm{ns}}$ & $7.72^{\mathrm{ns}}$ \\
\hline Types of Salinity & (5) & $0.19^{* *}$ & $546.16^{* *}$ \\
\hline$\hat{\mathrm{y}}_{1}$ & 1 & $0.86^{* *}$ & $2201.63^{* *}$ \\
\hline$\hat{y}_{2}$ & 1 & $0.06^{*}$ & $128.00^{*}$ \\
\hline$\hat{\mathrm{y}}_{3}$ & 1 & $0.07^{*}$ & $144.50^{*}$ \\
\hline$\hat{y}_{4}$ & 1 & $0.09^{*}$ & $264.50^{*}$ \\
\hline$\hat{\mathrm{y}}_{5}$ & 1 & $0.03^{\mathrm{ns}}$ & $135.20^{*}$ \\
\hline Residual & 15 & 0.01 & 15.85 \\
\hline $\mathrm{CV}$ & & 12.88 & 5.56 \\
\hline
\end{tabular}

$\hat{\mathrm{y}}_{1}\left(\mathrm{~S}_{1}\right.$ vs $\left.\mathrm{S}_{2}, \mathrm{~S}_{3}, \mathrm{~S}_{4}, \mathrm{~S}_{5}, \mathrm{~S}_{6}\right) ; \hat{\mathrm{y}}_{2}\left(\mathrm{~S}_{2}\right.$ vs $\left.\mathrm{S}_{3}\right) ; \hat{\mathrm{y}}_{3}\left(\mathrm{~S}_{2}\right.$ vs $\left.\mathrm{S}_{6}\right) ; \hat{\mathrm{y}}_{4}\left(\mathrm{~S}_{2}\right.$ vs $\left.\mathrm{S}_{5}\right) ; \hat{\mathrm{y}}_{5}\left(\mathrm{~S}_{5}\right.$ vs $\left.\mathrm{S}_{2}, \mathrm{~S}_{3}, \mathrm{~S}_{4}, \mathrm{~S}_{6}\right) ; \mathrm{VS}$ - variation source; $\mathrm{CV}$ - coefficient of variation; (*) and (**) significant at 0.05 and 0.01 probability, respectively; (ns) not significant.

The ESI of castor bean seedlings (Figure 1A) was significantly higher in plants subjected to irrigation using low-salinity water (control), with a mean value of 1.30 seedlings day ${ }^{-1}$, than in the other treatments $\left(\mathrm{S}_{2} ; \mathrm{S}_{3} ; \mathrm{S}_{4} ; \mathrm{S}_{5}\right.$; and $\left.\mathrm{S}_{6}\right)$, which had a mean ESI of 0.79 seedlings day ${ }^{-1}$ and did not differ $(p>$ 0.05 ) among themselves. The lower ESI values in plants irrigated with $4.5 \mathrm{dS} \mathrm{m}^{-1}$ water, than the ESI values of the control, indicate higher sensitivity of the cultivar "BRS Energia" to ECw variation than to the cationic composition of the water, confirming the moderate sensitivity of castor beans to salinity found by Ayers and Westcot (1999).

According to the contrasts of means for the ESI (Table 4), the differences between $\mathrm{S}_{1}$ and $\mathrm{S}_{2}, \mathrm{~S}_{3}$, $\mathrm{S}_{4}, \mathrm{~S}_{5}, \mathrm{~S}_{6} ; \mathrm{S}_{2}$ and $\mathrm{S}_{3} ; \mathrm{S}_{2}$ and $\mathrm{S}_{6}$; and $\mathrm{S}_{2}$ and $\mathrm{S}_{5}$ were significant. The mean ESI for plants irrigated with $0.6 \mathrm{dS} \mathrm{m}^{-1}$ water $\left(\mathrm{S}_{1}\right)$ was 0.51 seedlings day ${ }^{-1}$ higher than that for plants irrigated with $4.5 \mathrm{dS} \mathrm{m}^{-1}$ water, while for plants irrigated with $\mathrm{S}_{2}$ water (sodium), the mean ESI was $0.17,0.19$, and 0.22 seedlings day $^{-1}$ lower than water prepared with calcium, calcium + sodium, and potassium, respectively, confirming the stronger deleterious effect of sodium on ESI.

The decrease in the emergence of castor bean seedlings in this study was possibly due to the reduction of the osmotic potential of the soil solution resulting from the increment of salinity levels, directly affecting water absorption (GRACIANO et al., 2011). In this context, Nobre et al. (2013), upon evaluating the effects of irrigation with different ECw levels (from 0.4 to $4.4 \mathrm{dS} \mathrm{m}^{-1}$ ) on the emergence of the castor bean cultivar 'BRS Energia', observed that ESI was affected by salinity, with a decrease of $13.21 \%$ in plants irrigated with $4.4 \mathrm{dS} \mathrm{m}^{-1}$ water prepared using $\mathrm{NaCl}$, compared with the ESI values of the plants irrigated with $0.4 \mathrm{dS} \mathrm{m}^{-1}$ water. 
Figure 1. Emergence speed index - ESI (A) and percent emergence (B) of seedlings of castor bean cv. 'BRS Energia', with different types of irrigation water salinity.
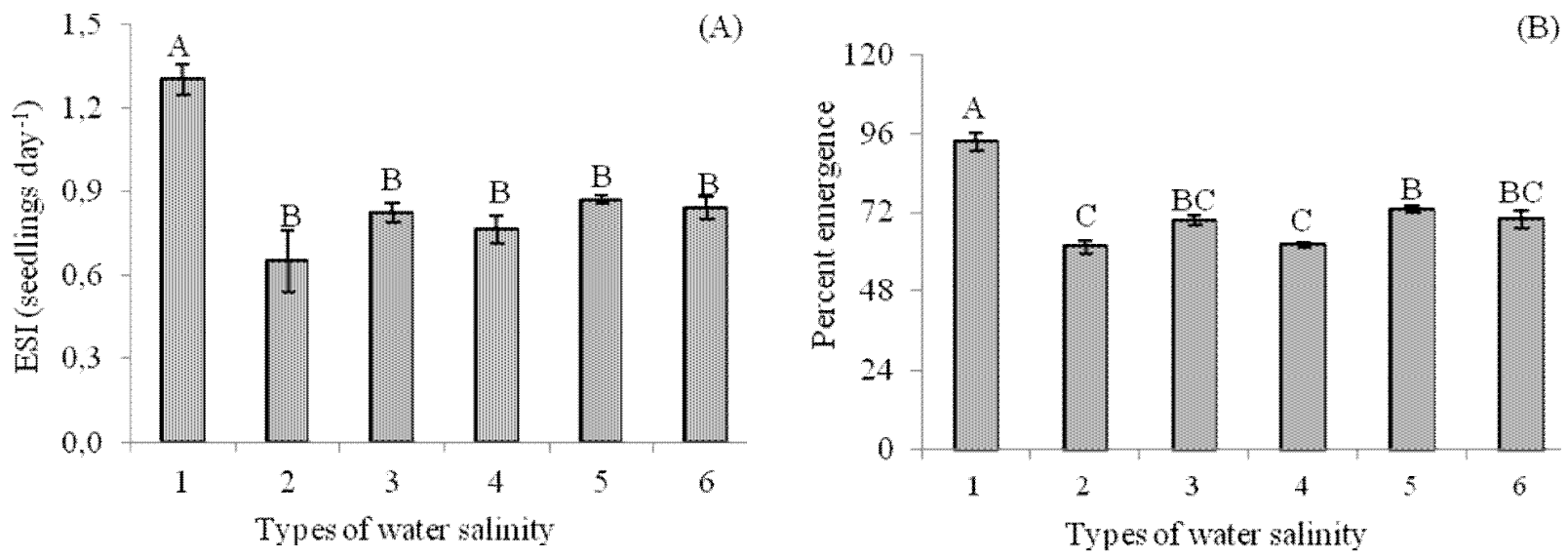

$1=$ Control; $2=\mathrm{Na}^{+} ; 3=\mathrm{Ca}^{2+} ; 4=\mathrm{Na}^{+}+\mathrm{Ca}^{2+} ; 5=\mathrm{K}^{+} ; 6=\mathrm{Na}^{+}+\mathrm{Ca}^{2+}+\mathrm{Mg}^{2+}$.

Table 4. Estimated means of different contrasts $(\hat{y})$ related to the emergence speed index (ESI) and percent emergence (EP) of castor bean cv. 'BRS Energia' irrigated with water of different types of salinity.

\begin{tabular}{ccc}
\hline \multirow{2}{*}{ Contrasts } & \multicolumn{3}{c}{ Mean estimate } \\
\cline { 2 - 3 } & ESI (seedlings day $\left.{ }^{-1}\right)$ & EP (\%) \\
\hline$\hat{y}_{1}$ & 0.51 & 25.70 \\
$\hat{y}_{2}$ & -0.17 & -8.00 \\
$\hat{y}_{3}$ & -0.19 & -8.50 \\
$\hat{y}_{4}$ & -0.22 & -11.50 \\
$\hat{y}_{5}$ & $n s$ & 6.50 \\
\hline
\end{tabular}

Contrasts: $\hat{\mathrm{y}}_{1}\left(\mathrm{~S}_{1} \mathrm{vs}_{2} ; \mathrm{S}_{3} ; \mathrm{S}_{4} ; \mathrm{S}_{5} ; \mathrm{S}_{6}\right) ; \hat{\mathrm{y}}_{2}\left(\mathrm{~S}_{2}\right.$ vs $\left.\mathrm{S}_{3}\right) ; \hat{\mathrm{y}}_{3}\left(\mathrm{~S}_{2} \mathrm{vs}_{6}\right) ; \hat{\mathrm{y}}_{4}\left(\mathrm{~S}_{2} \mathrm{vs} \mathrm{S}_{5}\right) ; \hat{\mathrm{y}}_{5}\left(\mathrm{~S}_{5} \mathrm{vs}_{2} ; \mathrm{S}_{3} ; \mathrm{S}_{4} ; \mathrm{S}_{6}\right) ;(\mathrm{ns})$ (ns) not significant.

The highest EP value (93.5\%) was observed for plants irrigated with low-salinity water (control), which was significantly higher than in the other treatments (Figure 1B). Lima et al. (2014), studying the influence of irrigation with saline water with

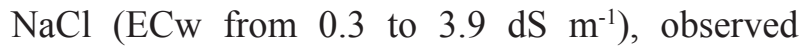
a higher EP (75.47\%) in castor bean plants that received $0.3 \mathrm{dS} \mathrm{m}^{-1}$ water and a lower EP (23.16\%) in plants under $3.9 \mathrm{dS} \mathrm{m}^{-1}$ water. Among the $\mathrm{S}_{2}, \mathrm{~S}_{3}$, $\mathrm{S}_{4}, \mathrm{~S}_{5}$, and $\mathrm{S}_{6}$ treatments (Table 4), the EP of plants irrigated with water containing potassium differed significantly $(p<0.05)$ from those under irrigation with water containing sodium or calcium. However, there was no significant variation $(p>0.05)$ between the $\mathrm{S}_{3}, \mathrm{~S}_{5}$, and $\mathrm{S}_{6}$ treatments.

As shown in the summary of the analysis of variance (Table 5), there was a significant influence of the different types of salinity on $\mathrm{PH}, \mathrm{SD}$, and LA in both evaluated periods (20 and 60 DAS). In a study using the castor bean cultivar 'BRS 149 Nordestina', Cavalcanti et al. (2005) observed a significant influence of the ionic proportions of $\mathrm{Na}^{+}$ $+\mathrm{Ca}^{2+}$ in the irrigation water only on plant height at 80 DAS. 
Table 5. Summary of analysis of variance in plant height (PH), stem diameter (SD), and leaf area (LA) at 20 and 60 days after sowing (DAS) of castor bean cv. 'BRS Energia' irrigated with water of different types of salinity.

\begin{tabular}{|c|c|c|c|c|c|c|c|}
\hline \multirow{3}{*}{ SV/Contrasts } & \multirow{3}{*}{ GL } & \multicolumn{6}{|c|}{ Mean square } \\
\hline & & \multicolumn{2}{|c|}{$\mathrm{PH}$} & \multicolumn{2}{|c|}{ SD } & \multicolumn{2}{|r|}{ LA } \\
\hline & & $20 \mathrm{DAS}$ & $60 \mathrm{DAS}$ & $20 \mathrm{DAS}$ & $60 \mathrm{DAS}$ & $20 \mathrm{DAS}$ & $60 \mathrm{DAS}$ \\
\hline Blocks & 3 & $0.68^{\mathrm{ns}}$ & $9.03^{\text {ns }}$ & $0.007^{\mathrm{ns}}$ & $4.97^{\mathrm{ns}}$ & $255.64^{\text {ns }}$ & $971979.14^{\mathrm{ns}}$ \\
\hline Types of Salinity & (5) & $11.86^{* *}$ & $511.62^{* *}$ & $0.30^{* *}$ & $30.47^{*}$ & $13896.14^{* *}$ & $103518637.38^{* *}$ \\
\hline$\hat{\mathrm{y}}_{1}$ & 1 & $54.85^{* *}$ & $2324.06^{* * *}$ & $1.35^{* *}$ & $142.05^{* *}$ & $62034.22^{* *}$ & $515438865.94^{* *}$ \\
\hline$\hat{\mathrm{y}}_{2}$ & 1 & $1.219^{\mathrm{ns}}$ & $0.65^{\mathrm{ns}}$ & $0.05^{\mathrm{ns}}$ & $0.26^{\mathrm{ns}}$ & $2511.17^{*}$ & $1134419.38^{\mathrm{ns}}$ \\
\hline$\hat{\mathrm{y}}_{3}$ & 1 & $0.87^{\mathrm{ns}}$ & $27.81^{\mathrm{ns}}$ & $0.04^{\mathrm{ns}}$ & $0.003^{\text {ns }}$ & $710.73^{*}$ & $786653.68^{\text {ns }}$ \\
\hline$\hat{y}_{4}$ & 1 & $3.84^{*}$ & $184.63^{* *}$ & $0.12^{*}$ & $7.39^{\mathrm{ns}}$ & $3967.17^{* *}$ & $1891490.13^{\text {ns }}$ \\
\hline$\hat{y}_{5}$ & 1 & $2.87^{*}$ & $195.88^{* *}$ & $0.03^{\mathrm{ns}}$ & $9.07^{\mathrm{ns}}$ & $3324.06^{* *}$ & $851841.29^{\mathrm{ns}}$ \\
\hline Residual & 15 & 0.72 & 10.98 & 0.02 & 3.85 & 135.71 & 116655.42 \\
\hline $\mathrm{CV}$ & & 8.43 & 5.93 & 3.18 & 12.38 & 8.99 & 20.93 \\
\hline
\end{tabular}

$\hat{\mathrm{y}}_{1}\left(\mathrm{~S}_{1}\right.$ vs $\left.\mathrm{S}_{2}, \mathrm{~S}_{3}, \mathrm{~S}_{4}, \mathrm{~S}_{5}, \mathrm{~S}_{6}\right) ; \hat{\mathrm{y}}_{2}\left(\mathrm{~S}_{2}\right.$ vs $\left.\mathrm{S}_{3}\right) ; \hat{\mathrm{y}}_{3}\left(\mathrm{~S}_{2}\right.$ vs $\left.\mathrm{S}_{6}\right) ; \hat{\mathrm{y}}_{4}\left(\mathrm{~S}_{2}\right.$ vs $\left.\mathrm{S}_{5}\right) ; \hat{\mathrm{y}}_{5}\left(\mathrm{~S}_{5}\right.$ vs $\left.\mathrm{S}_{2}, \mathrm{~S}_{3}, \mathrm{~S}_{4}, \mathrm{~S}_{6}\right)$; VS - variation source; $\mathrm{CV}$ - coefficient of variation; $(*)$ and (**) significant at 0.05 and 0.01 probability, respectively; (ns) not significant.

Irrigation using water of different ionic compositions had a significant influence on the $\mathrm{PH}$ of castor beans at 20 DAS (Figure 2A), and, based on the comparison of means, the $\mathrm{S}_{1}$ (control) treatment had significantly higher $\mathrm{PH}$ values (13.46 $\mathrm{cm})$ than the other treatments $\left(\mathrm{S}_{2} ; \mathrm{S}_{3} ; \mathrm{S}_{4} ; \mathrm{S}_{5}\right.$; and $\left.\mathrm{S}_{6}\right)$. However, when plants were subjected to irrigation with water containing different cations at an $\mathrm{ECw}$ of $4.5 \mathrm{dS} \mathrm{m}^{-1}$, plant height was not significantly influenced $(\mathrm{p}>0.05)$. From the results of $\mathrm{PH}$ at 20 DAS, it is possible to infer that the effect of salinity on the initial growth of castor beans is related to the total salt concentration.

According to the mean comparison (Figure 2B), plants irrigated with low-salinity water $\left(\mathrm{S}_{1}\right)$ had a higher PH at 60 DAS $(77.94 \mathrm{~cm})$ than plants irrigated with high-salinity water of different ionic compositions $\left(\mathrm{S}_{2} ; \mathrm{S}_{3} ; \mathrm{S}_{4} ; \mathrm{S}_{5}\right.$; and $\left.\mathrm{S}_{6}\right)$. Further, plants in the potassium treatment had a significantly higher
PH than the treatments with sodium and calcium, and did not differ from the treatments with sodium + calcium and sodium + calcium + magnesium (Figure 2B).

According to the contrasts of means (Table 5), the $\mathrm{PH}$ of plants irrigated with $0.6 \mathrm{dS} \mathrm{m} \mathrm{m}^{-1}$ water $\left(\mathrm{S}_{1}\right)$ varied significantly $(\mathrm{p}<0.05)$ from those with an $\mathrm{ECW}$ of $4.5 \mathrm{dS} \mathrm{m}^{-1}$ in both evaluated periods. According to the estimate of the mean (Table 6), plants irrigated with low-salinity water $(0.6 \mathrm{dS}$ $\mathrm{m}^{-1}$ ) had increases of 4.05 and $26.40 \mathrm{~cm}$ in $\mathrm{PH}$, compared with the mean for those with an ECw of $4.5 \mathrm{dS} \mathrm{m}^{-1}\left(\mathrm{~S}_{2} ; \mathrm{S}_{3} ; \mathrm{S}_{4} ; \mathrm{S}_{5} ;\right.$ and $\left.\mathrm{S}_{6}\right)$ at 20 and $60 \mathrm{DAS}$, respectively. The results obtained in this study agree with Lima et al. (2014), who observed that the increase in the salinity of irrigation water (EC from 0.3 to $3.9 \mathrm{dS} \mathrm{m}^{-1}$ ) significantly reduced the plant height of the castor bean cultivar 'BRS Energia' at 30,60 , and 120 DAS. 
Figure 2. Plant height of castor bean cv. 'BRS Energia' at 20 (A) and 60 (B) days after sowing, with different types of irrigation water salinity.
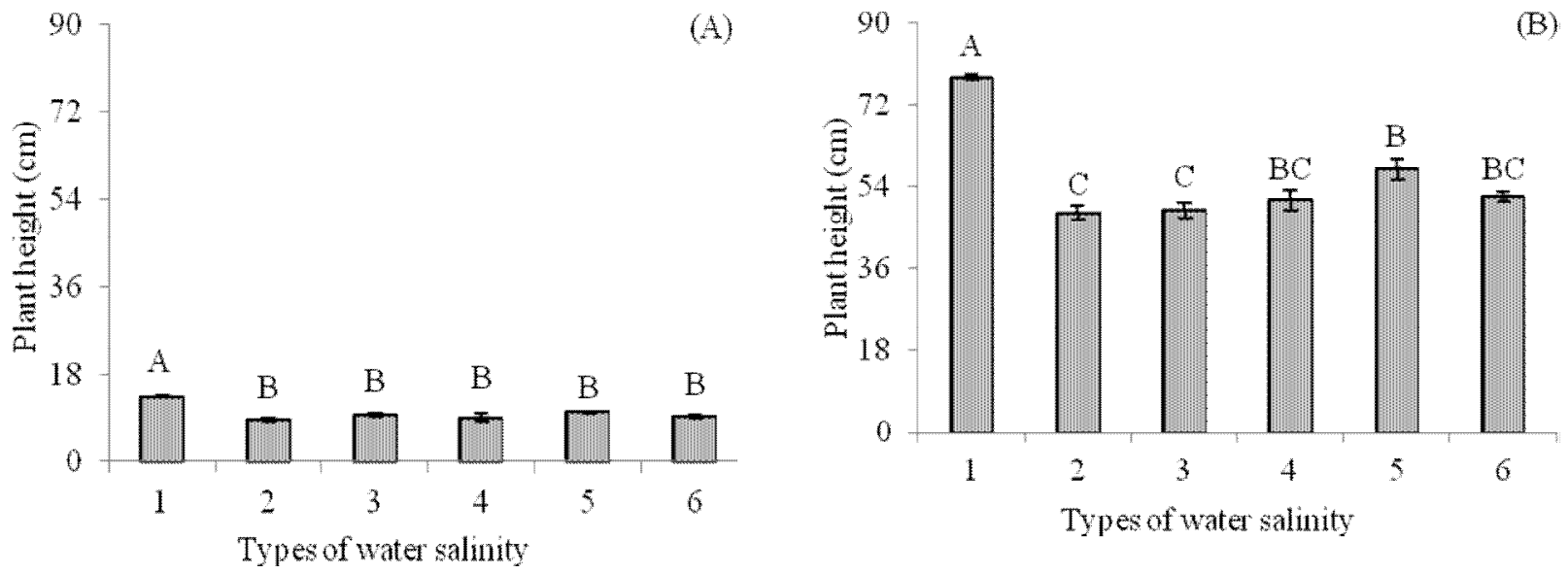

$1=$ Control; $2=\mathrm{Na}^{+} ; 3=\mathrm{Ca}^{2+} ; 4=\mathrm{Na}^{+}+\mathrm{Ca}^{2+} ; 5=\mathrm{K}^{+} ; 6=\mathrm{Na}^{+}+\mathrm{Ca}^{2+}+\mathrm{Mg}^{2+}$.

There was no significant effect $(\mathrm{p}>0.05)$ between the $\mathrm{S}_{2}$ and $\mathrm{S}_{3}$ treatments or between the $\mathrm{S}_{2}$ and $\mathrm{S}_{6}$ treatments in any of the evaluated periods. Thus, the results suggest that water containing sodium, calcium, and sodium + calcium + magnesium acted similarly on castor bean growth. On the other hand, there were significant differences $(p<0.05)$ between the treatments $\mathrm{S}_{2}$ and $\mathrm{S}_{5}$ and between $\mathrm{S}_{5}$ and $\mathrm{S}_{2}, \mathrm{~S}_{3}$, $\mathrm{S}_{4}$, and $\mathrm{S}_{6}$ in both studied periods, and, according to the estimates of the means (Table 6), plants irrigated with water containing sodium $\left(\mathrm{S}_{2}\right)$ had a $\mathrm{PH} 1.38$ and $9.60 \mathrm{~cm}$ lower than plants irrigated with water containing potassium $\left(\mathrm{S}_{5}\right)$ at 20 and 60 DAS, respectively. Santos et al. (2012) claim that this tendency for $\mathrm{PH}$ reduction under conditions of saline stress can be attributed to the fact that, in order to adjust osmotically, plants spend energy to accumulate sugars, organic acids, and ions in the vacuole, which could instead be used for growth.

On the other hand, plants irrigated with water containing potassium $\left(\mathrm{S}_{5}\right)$ had a higher $\mathrm{PH}$ than the other types of water $\left(\mathrm{S}_{2} ; \mathrm{S}_{3} ; \mathrm{S}_{4}\right.$; and $\left.\mathrm{S}_{6}\right)$, with mean values of 0.94 and $7.82 \mathrm{~cm}$ at 20 and 60 DAS, respectively. This reflects the importance of potassium in plant metabolism, since it acts in the regulation of cell osmotic potential and is essential for balancing the negative charges of the organic acids inside cells and for balancing the anions absorbed by roots (BERNARDI et al., 2010).

According to the mean comparison test (Figure $3 \mathrm{~A}$ and $\mathrm{B}$ ), plants irrigated with low-salinity water $\left(\mathrm{S}_{1}\right)$ had the highest SD means at 20 and $60 \mathrm{DAS}$, significantly greater than those under irrigation in the treatments $\mathrm{S}_{2}, \mathrm{~S}_{3}, \mathrm{~S}_{4}, \mathrm{~S}_{5}$, and $\mathrm{S}_{6}$, which did not differ $(p>0.05)$ among themselves. However, the differences among the aforementioned treatments increased as plants aged.

Similarly to $\mathrm{PH}$, according to the contrasts (Table 5), there were significant differences in SD between plants irrigated with $0.6 \mathrm{dS} \mathrm{m} \mathrm{m}^{-1}$ water $\left(\mathrm{S}_{1}\right)$ and those receiving $4.5 \mathrm{dS} \mathrm{m}^{-1}$ water in both evaluated periods. Plants irrigated with $0.6 \mathrm{dS} \mathrm{m}^{-1}$ water had mean values 0.63 and $6.53 \mathrm{~mm}$ greater at 20 and 60 DAS, respectively, than plants receiving $4.5 \mathrm{dS} \mathrm{m}^{-1}$ water (Table 6). Alves et al. (2012), upon studying the influence of irrigation with $\mathrm{ECw}$ ranging from 0.6 to $4.6 \mathrm{dS} \mathrm{m}^{-1}$ on the growth of the castor bean cultivar "BRS Energia", observed a reduction of $3.32 \mathrm{~mm}$ in stem diameter at 40 DAS. 
Table 6. Estimated means of different contrasts ( $\hat{y})$ related to plant height (PH), stem diameter (SD), and leaf area (LA) of castor bean cv. 'BRS Energia' irrigated with water of different types of salinity, at 20 and 60 days after sowing (DAS)

\begin{tabular}{ccccccc}
\hline \multirow{2}{*}{ Contrasts } & \multicolumn{7}{c}{ Mean estimate } \\
\cline { 2 - 7 } & $20 \mathrm{DAS}$ & 60 DAS & 20 DAS & 60 DAS & 20 DAS & LA DAS $\left(\mathrm{cm}^{2}\right)$ \\
\hline$\hat{y}_{1}$ & 4.05 & 26.40 & 0.63 & 6.52 & 136.41 & 12435.09 \\
$\hat{y}_{2}$ & $\mathrm{~ns}$ & $\mathrm{~ns}$ & $\mathrm{~ns}$ & $\mathrm{~ns}$ & -35.43 & $\mathrm{~ns}$ \\
$\hat{\mathrm{y}}_{3}$ & $\mathrm{~ns}$ & $\mathrm{~ns}$ & $\mathrm{~ns}$ & $\mathrm{~ns}$ & -18.85 & $\mathrm{~ns}$ \\
$\hat{\mathrm{y}}_{4}$ & -1.38 & -9.60 & -0.24 & $\mathrm{~ns}$ & -44.53 & $\mathrm{~ns}$ \\
$\hat{\mathrm{y}}_{5}$ & 0.94 & 7.82 & $\mathrm{~ns}$ & $\mathrm{~ns}$ & 32.22 & $\mathrm{~ns}$ \\
\hline
\end{tabular}

Contrasts: $\hat{\mathrm{y}}_{1}\left(\mathrm{~S}_{1} \mathrm{vs} \mathrm{S}_{2} ; \mathrm{S}_{3} ; \mathrm{S}_{4} ; \mathrm{S}_{5} ; \mathrm{S}_{6}\right) ; \hat{\mathrm{y}}_{2}\left(\mathrm{~S}_{2} \mathrm{vs}_{3}\right) ; \hat{\mathrm{y}}_{3}\left(\mathrm{~S}_{2} \mathrm{vs}_{6}\right) ; \hat{\mathrm{y}}_{4}\left(\mathrm{~S}_{2} \mathrm{vs}_{5}\right) ; \hat{\mathrm{y}}_{5}\left(\mathrm{~S}_{5} \mathrm{vs}_{2} ; \mathrm{S}_{3} ; \mathrm{S}_{4} ; \mathrm{S}_{6}\right) ;(\mathrm{ns})$ (ns) not significant.

Figure 3. Stem diameter of castor bean cv. 'BRS Energia' at 20 (A) and 60 (B) days after sowing, with different types of irrigation water salinity.


$1=$ Control; $2=\mathrm{Na}^{+} ; 3=\mathrm{Ca}^{2+} ; 4=\mathrm{Na}^{+}+\mathrm{Ca}^{2+} ; 5=\mathrm{K}^{+} ; 6=\mathrm{Na}^{+}+\mathrm{Ca}^{2+}+\mathrm{Mg}^{2+}$.

According to Table 5, the SD of plants in the $\mathrm{S}_{2}$ treatment was not significantly different from the $S_{3}$ and $\mathrm{S}_{6}$ treatments in any of the evaluated periods. Thus, it is possible to infer that irrigation water with different types of salts $\left(\mathrm{Ca}^{2+}\right.$; and $\mathrm{Na}^{+}+\mathrm{Ca}^{2+}+$ $\mathrm{Mg}^{2+}$ ) had similar effects on $\mathrm{SD}$, but plants in the $\mathrm{S}_{2}$ treatment were significantly different from those in the $\mathrm{S}_{5}$ treatment at $20 \mathrm{DAS}$ and had SD values 0.24 $\mathrm{mm}$ lower than plants from $\mathrm{S}_{5}$.

According to the comparison of means, castor bean plants irrigated with low-salinity water (control) had a significantly higher $(\mathrm{p}<0.05) \mathrm{LA}$ at
20 DAS than plants irrigated with water containing sodium, calcium, sodium + calcium, potassium, and sodium + calcium + magnesium. In the comparison of means from different treatments, plants irrigated with water containing potassium $\left(\mathrm{S}_{5}\right)$ were significantly different $(p<0.05)$ from plants in the $\mathrm{S}_{2}$ and $\mathrm{S}_{4}$ treatments, but were similar to those under $\mathrm{S}_{3}$ and $\mathrm{S}_{6}$ (Figure 4A).

According to the mean comparison test (Figure 4B), plants irrigated with low-salinity water $\left(\mathrm{S}_{1}\right)$ had a higher LA at 60 DAS $\left(15410.2 \mathrm{~cm}^{2}\right)$ than the other treatments, which did not differ among themselves and had a mean value of $2871.90 \mathrm{~cm}^{2}$. 
Figure 4. Leaf area of castor bean cv. 'BRS Energia' at 20 (A) and 60 (B) days after sowing, with different types of irrigation water salinity.
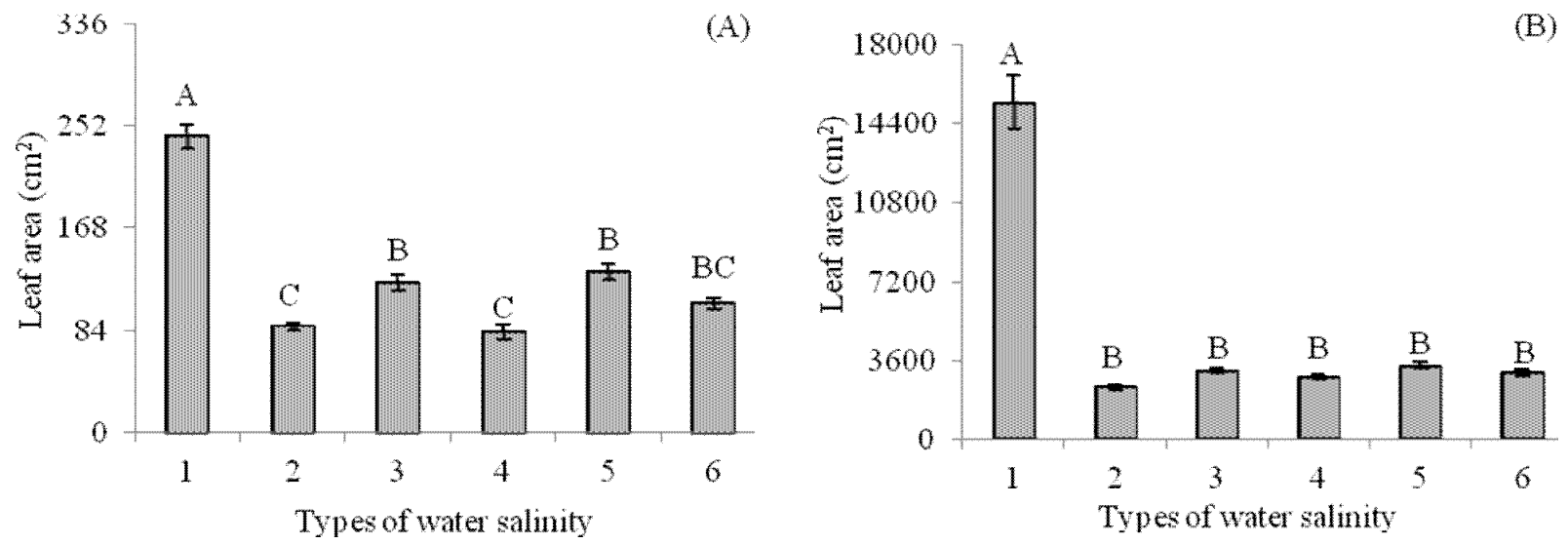

$1=$ Control; $2=\mathrm{Na}^{+} ; 3=\mathrm{Ca}^{2+} ; 4=\mathrm{Na}^{+}+\mathrm{Ca}^{2+} ; 5=\mathrm{K}^{+} ; 6=\mathrm{Na}^{+}+\mathrm{Ca}^{2+}+\mathrm{Mg}^{2+}$

The analysis of variance of the contrasts between the studied treatments for the LA of castor bean plants is shown in Table 5. At 20 DAS, all the studied contrasts were significant, while at 60 DAS only the contrast between waters of low and high salinity was significant. According to the estimate of the mean (Table 6), there was a greater ;increase in the LA of plants irrigated with $0.6 \mathrm{dS} \mathrm{m}^{-1}$ water, exceeding the mean value by 136.41 and 12435.09 $\mathrm{cm}^{2}$ at 20 and 60 DAS, respectively, compared with those irrigated with $4.5 \mathrm{dS} \mathrm{m}^{-1}$ water.

The LA of plants irrigated with water containing sodium $\left(\mathrm{S}_{2}\right)$ was only significantly different from those irrigated with water containing calcium $\left(\mathrm{S}_{3}\right)$ or sodium + calcium $\left(\mathrm{S}_{4}\right)$ at 20 DAS. Still, according to Table 5, a significant difference in LA between the $\mathrm{S}_{2}$ and $\mathrm{S}_{5}$ treatments was observed only at 20 DAS. According to the comparison of the castor bean growth through the estimate of the mean (Table 6), the LA of plants in the $\mathrm{S}_{2}$ treatment was significantly lower $(\mathrm{p}<0.05)$ by $44.53 \mathrm{~cm}^{2}$ than those in the $\mathrm{S}_{5}$ treatment at $20 \mathrm{DAS}$. In this sense, the decreases in
LA, notably in plants irrigated with water containing sodium, can reflect the accumulation of the ions $\mathrm{Na}^{+}$and $\mathrm{Cl}^{-}$in plant tissues at levels that change the cellular ionic balance.

However, $\mathrm{S}_{5}$ plants had an LA $32.22 \mathrm{~cm}^{2}$ more than plants in the other treatments with an $\mathrm{ECw}$ of $4.5 \mathrm{dS} \mathrm{m}^{-1}\left(\mathrm{~S}_{2} ; \mathrm{S}_{3} ; \mathrm{S}_{4}\right.$ and $\left.\mathrm{S}_{6}\right)$, i.e., a greater reduction than that observed previously between the treatments $\mathrm{S}_{2}$ and $\mathrm{S}_{5}$. According to the above results, plants irrigated with water containing potassium had greater leaf expansion than plants receiving other high-salt treatments, which may be associated with the functions of $\mathrm{K}^{+}$in plant metabolism, since this macronutrient participates in the maintenance of ionic balance and cell turgor by regulating stomatal opening and closure (GURGEL et al., 2010).

According to the summary of the analysis of variance (Table 7), there was a significant effect ( $p$ $<0.05$ ) of the different types of water salinity on the number of days for inflorescence development (NDI) and flower bud opening (NDFO). 
Table 7. Summary of analysis of variance related to the number of days for inflorescence development (NDI) and flower bud opening (NDFO) of castor bean cv. 'BRS Energia' irrigated with water of different types of salinity.

\begin{tabular}{|c|c|c|c|}
\hline \multirow{2}{*}{ SV/Contrasts } & \multirow{2}{*}{ GL } & \multicolumn{2}{|c|}{ Mean square } \\
\hline & & NDI & NDFO \\
\hline Blocks & 3 & $1.81^{\mathrm{ns}}$ & $6.27^{\mathrm{ns}}$ \\
\hline Types of Salinity & $(5)$ & $37.84^{*}$ & $33.66^{*}$ \\
\hline$\hat{y}_{1}$ & 1 & $78.40^{*}$ & $83.33^{*}$ \\
\hline$\hat{\mathrm{y}}_{2}$ & 1 & $72.40^{*}$ & $24.50^{*}$ \\
\hline$\hat{\mathrm{y}}_{3}$ & 1 & $0.50^{\mathrm{ns}}$ & $10.12^{\mathrm{ns}}$ \\
\hline$\hat{\mathrm{y}}_{4}$ & 1 & $2.00^{\mathrm{ns}}$ & $8.00^{\mathrm{ns}}$ \\
\hline$\hat{\mathrm{y}}_{5}$ & 1 & $3.61^{\mathrm{ns}}$ & $15.31^{\mathrm{ns}}$ \\
\hline Residual & 15 & 7.08 & 7.11 \\
\hline $\mathrm{CV}$ & & 6.82 & 5.75 \\
\hline
\end{tabular}

$\hat{\mathrm{y}}_{1}\left(\mathrm{~S}_{1}\right.$ vs $\left.\mathrm{S}_{2}, \mathrm{~S}_{3}, \mathrm{~S}_{4}, \mathrm{~S}_{5}, \mathrm{~S}_{6}\right) ; \hat{\mathrm{y}}_{2}\left(\mathrm{~S}_{2}\right.$ vs $\left.\mathrm{S}_{3}\right) ; \hat{\mathrm{y}}_{3}\left(\mathrm{~S}_{2}\right.$ vs $\left.\mathrm{S}_{6}\right) ; \hat{\mathrm{y}}_{4}\left(\mathrm{~S}_{2}\right.$ vs $\left.\mathrm{S}_{5}\right) ; \hat{\mathrm{y}}_{5}\left(\mathrm{~S}_{5}\right.$ vs $\left.\mathrm{S}_{2}, \mathrm{~S}_{3}, \mathrm{~S}_{4}, \mathrm{~S}_{6}\right) ; \mathrm{VS}$ - variation source; $\mathrm{CV}$ - coefficient of variation; $\left(^{*}\right)$ and $(* *)$ significant at 0.05 and 0.01 probability; (ns) not significant.

NDI was significantly influenced by irrigation with water of different salinity and, according to the means comparison test (Figure 5A), plants irrigated with water containing calcium $\left(\mathrm{S}_{3}\right)$ had a significantly higher NDI than those receiving
$\mathrm{S}_{1}$ treatment. Similar to NDI, NDFO varied significantly only between the control $\left(\mathrm{S}_{1}\right)$ and the $\mathrm{S}_{3}$ treatment (Figure 5B). Thus, the increase in NDI leads to the delay in the beginning of flowering and, consequently, in the completion of the crop cycle.

Figure 5. Number of days for inflorescence development - NDI (A) and flower bud opening - NDFO (B) of castor bean cv. 'BRS Energia', with different types of irrigation water salinity.
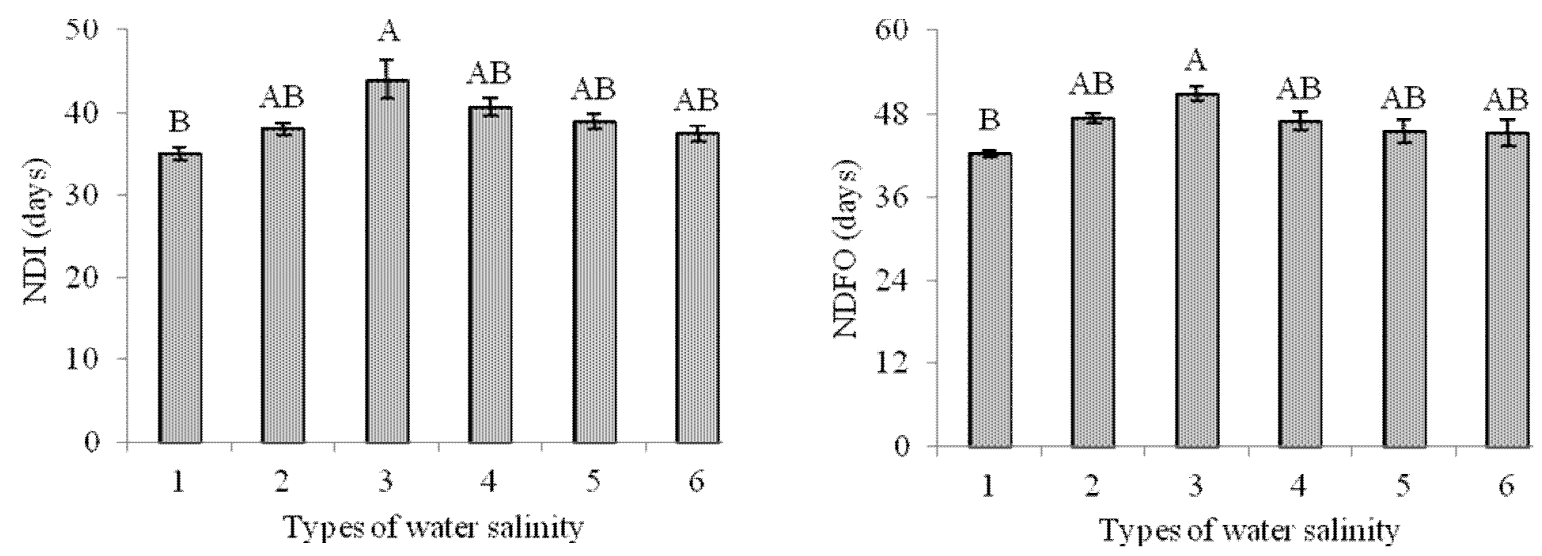

$1=$ Control; $2=\mathrm{Na}^{+} ; 3=\mathrm{Ca}^{2+} ; 4=\mathrm{Na}^{+}+\mathrm{Ca}^{2+} ; 5=\mathrm{K}^{+} ; 6=\mathrm{Na}^{+}+\mathrm{Ca}^{2+}+\mathrm{Mg}^{2+}$

According to the contrasts for NDI (Table 7), plants irrigated with $0.6 \mathrm{dS} \mathrm{m}^{-1}$ water $\left(\mathrm{S}_{1}\right)$ were significantly different from those receiving $4.5 \mathrm{dS} \mathrm{m}^{-1}$ water $\left(\mathrm{S}_{2} ; \mathrm{S}_{3} ; \mathrm{S}_{4} ; \mathrm{S}_{5}\right.$; and $\left.\mathrm{S}_{6}\right)$, and, according to the estimate of the mean (Table 8 ), plants irrigated with low-salinity water $\left(0.6 \mathrm{dS} \mathrm{m}^{-1}\right)$ had an NDI 4.85 days earlier than plants receiving $4.5 \mathrm{dS} \mathrm{m}^{-1}$ water $\left(\mathrm{S}_{2} ; \mathrm{S}_{3}\right.$;
$\mathrm{S}_{4} ; \mathrm{S}_{5}$; and $\mathrm{S}_{6}$ ). In addition, there was a significant difference $(p<0.05)$ in NDI between the $S_{2}$ and $S_{3}$ treatments (Table 7), and according to the estimate of the mean (Table 8), when water containing sodium $\left(\mathrm{S}_{2}\right)$ was used for irrigation, the NDI was statistically lower, with a decrease of 6.00 days compared with plants in the $\mathrm{S}_{3}$ treatment (calcium). Analyzing the 
effects of the treatments $\left(\mathrm{S}_{2}\right.$ vs $\mathrm{S}_{6} ; \mathrm{S}_{2}$ vs $\mathrm{S}_{5}$; and $\mathrm{S}_{5}$ vs the others $\left(\mathrm{S}_{2} ; \mathrm{S}_{3} ; \mathrm{S}_{4}\right.$; and $\left.\left.\mathrm{S}_{6}\right)\right)$, there was no significant influence $(p>0.05)$ on NDI.

According to the summary of the analysis of variance for the contrasts of means for NDFO (Table 7), there was a significant difference only between $\mathrm{S}_{1}$ and the other treatments $\left(\mathrm{S}_{2} ; \mathrm{S}_{3} ; \mathrm{S}_{4} ; \mathrm{S}_{5}\right.$; and $\mathrm{S}_{6}$ ) and between $\mathrm{S}_{2}$ and $\mathrm{S}_{3}$. According to the estimate of the mean (Table 8), flower bud opening was delayed by 5.00 days when comparing plants receiving $0.6 \mathrm{dS} \mathrm{m}^{-1}$ and $4.5 \mathrm{dS} \mathrm{m}^{-1}$ water. When NDFO was analyzed between plants irrigated with sodium water $\left(\mathrm{S}_{2}\right)$ and calcium water $\left(\mathrm{S}_{3}\right)$, there was a delay of 3.5 days. The fact that NDI and NDFO increased with increasing ionic composition can also be related to the genetics of the plant, which adjusts osmotically in the initial development stage and spends more energy for the accumulation of sugars, organic acids, and ions in the vacuole, instead of plant growth and yield. Consequently, flowering is delayed (SANTOS et al., 2012).

Table 8. Estimated means of different contrasts ( $\hat{y}$ ) related to the number of days for inflorescence development (NDI) and flower bud opening (NDFO) of castor bean cv. 'BRS Energia' irrigated with water of different types of salinity.

\begin{tabular}{ccc}
\hline \multirow{2}{*}{ Contrasts } & \multicolumn{3}{c}{ Mean estimate } \\
\cline { 2 - 3 } & NDI (days) & NDFO (days) \\
\hline$\hat{y}_{1}$ & -4.85 & -5.00 \\
$\hat{y}_{2}$ & -6.00 & -3.50 \\
$\hat{y}_{3}$ & $n s$ & $n s$ \\
$\hat{y}_{4}$ & $n s$ & $n s$ \\
$\hat{y}_{5}$ & $n s$ & $n s$ \\
\hline
\end{tabular}

Contrasts: $\hat{\mathrm{y}}_{1}\left(\mathrm{~S}_{1}\right.$ vs $\left.\mathrm{S}_{2} ; \mathrm{S}_{3} ; \mathrm{S}_{4} ; \mathrm{S}_{5} ; \mathrm{S}_{6}\right) ; \hat{\mathrm{y}}_{2}\left(\mathrm{~S}_{2}\right.$ vs $\left.\mathrm{S}_{3}\right) ; \hat{\mathrm{y}}_{3}\left(\mathrm{~S}_{2}\right.$ vs $\left.\mathrm{S}_{6}\right) ; \hat{\mathrm{y}}_{4}\left(\mathrm{~S}_{2}\right.$ vs $\left.\mathrm{S}_{5}\right) ; \hat{\mathrm{y}}_{5}\left(\mathrm{~S}_{5}\right.$ vs $\left.\mathrm{S}_{2} ; \mathrm{S}_{3} ; \mathrm{S}_{4} ; \mathrm{S}_{6}\right) ;(\mathrm{ns})$ (ns) not significant.

\section{Conclusions}

The emergence and growth of castor beans up to 60 days after planting were more affected by ECw than by the cationic composition of the irrigation water.

The negative effects of saline stress on the emergence and growth of the castor bean cultivar 'BRS Energia' vary with the type of cation in the irrigation water and follow the order: $\mathrm{Na}^{+}>\mathrm{Na}^{+}+$ $\mathrm{Ca}^{2+}>\mathrm{Ca}^{2+}>\mathrm{Na}^{+}+\mathrm{Ca}^{2+}+\mathrm{Mg}^{2+}>\mathrm{K}^{+}$.

The cationic composition of the irrigation water influences the time required for emission of inflorescence and the opening of flower buds of the castor bean cultivar 'BRS Energia', and the most pronounced effects were observed in plants irrigated with water containing calcium.

\section{References}

ALVES, A. N.; GHEYI, H. R.; UYEDA, C. A.; SOARES, F. A. L.; NOBRE, R. G.; CARDOSO, J. A. F. Uso de águas salinas e adubação nitrogenada no cultivo da mamoneira BRS-Energia. Revista Brasileira de Agricultura Irrigada, Fortaleza, v. 6, n. 2, p. 151-163, 2012.

ASHRAF, M.; HARRIS, P. J. C. Potential biochemical indicators of salinity tolerance in plants. Plant Science, Dordrecht, v. 166, n. 1, p. 3-16, 2004.

AYERS, R. S.; WESTCOT, D. W. A qualidade da água na agricultura. Campina Grande: UFPB, 1999. 153 p. (Estudos FAO: Irrigação e drenagem, 29).

BABITA, M.; MAHESWARI, M.; RAO, L. M.; SHANKER, A. K.; RAO, A. K.; RAO, D. G. Osmotic adjustment, drought tolerance and yield in castor (Ricinus communis L.) hybrids. Environmental and Experimental Botany, Elmsford, v. 69, n. 3, p. 243-249, 2010.

BERNARDI, A. C. C.; OKA, S. H.; SOUZA, G. B. de. Comparação de técnicas analíticas para a extração de potássio de amostras de tecido vegetal com água e soluções ácidas concentradas e diluída. Eclética Química, São Paulo, v. 35, n. 2, p. 45-49, 2010.

BEZERRA, A. K. P.; LACERDA, C. F. de; HERNANDEZ, F. F. F.; SILVA, F. B. da; GHEYI, H. R. Rotação cultural feijão caupi/milho utilizando-se águas de salinidades diferentes. Revista Ciência Rural, Santa Maria, v. 40, n. 5, p. 1075-1082, 2010. 
CAMPOS, V. B.; CAVALCANTE, L. F.; RODOLFO JÚNIOR, F.; SOUSA, G. G.; MOTA, J. K. Crescimento inicial da mamoneira em resposta à salinidade e biofertilizante bovino. Magistra, Cruz das Almas, v. 21, n. 1, p. 41-47, 2009.

CAVALCANTI, M. L. F.; FERNANDES, P. D.; GHEYI, H. R.; BARROS JÚNIOR, G.; SOARES, F. A. L.; SIQUEIRA, E. da C. Tolerância da mamoneira BRS 149 à salinidade: germinação e características de crescimento. Revista Brasileira de Engenharia Agrícola e Ambiental, Campina Grande, v. 9, p. 57-61, 2005. Suplemento.

CLAESSEN, M. E. C. (Org.). Manual de métodos de análise de solo. 2. ed. rev. atual. Rio de Janeiro: EmbrapaCNPS, 1997. 212 p. (Embrapa-CNPS. Documentos, 1).

COSTA, R. G.; GHEYI, H. R. Variação da qualidade da água de irrigação da microrregião homogênea de Catolé do Rocha, PB. Pesquisa Agropecuária Brasileira, Brasília, v. 19, n. 8, p. 1021-1025, 1984.

GRACIANO, E. S. A.; NOGUEIRA, R. J. M. C.; LIMA, D. R. M.; PACHECO, C. M.; SANTOS, R. C. Crescimento e capacidade fotossintética da cultivar de amendoim BR 1 sob condições de salinidade. Revista Brasileira de Engenharia Agrícola e Ambiental, Campina Grande, v. 15, n. 8, p. 794-800, 2011.

GURGEL, M. T.; UYEDA, C. A.; GHEYI, H. R.; OLIVEIRA, F. H. T. de; FERNANDES, P. D.; SILVA, F. V. da. Crescimento de meloeiro sob estresse salino e doses de potássio. Revista Brasileira de Engenharia Agrícola e Ambiental, Campina Grande, v. 14, n. 1, p. 3-10, 2010.

LIMA, G. S. de; NOBRE, R. G.; GHEYI, H. R.; SOARES, L. A. dos A.; SILVA, S. S. da. Respostas morfofisiológicas da mamoneira, em função da salinidade da água de irrigação e adubação nitrogenada. Irriga, Botucatu, v. 19, n. 1, p. 130-136, 2014.

NOBRE, R. G.; GHEYI, H. R.; SOARES, F. A. L.; CARDOSO, J. A. F. Produção de girassol sob estresse salino e adubação nitrogenada. Revista Brasileira de Ciência do Solo, Viçosa, v. 35, n. 3, p. 929-937, 2011.

NOBRE, R. G.; LIMA, G. S. de; GHEYI, H. R.; LOURENÇO, G. S.; SOARES, L. A. A. Emergência, crescimento e produção da mamoneira sob estresse salino e adubação nitrogenada. Revista Ciência Agronômica, Fortaleza, v. 44, n. 1, p. 76-85, 2013.

NOVAIS, R. F.; NEVES, J. C. L.; BARROS, N. F. Ensaio em ambiente controlado. In: OLIVEIRA, A. J. (Ed.). Métodos de pesquisa em fertilidade do solo. Brasília: Embrapa-SEA, 1991. p. 189-253.

RICHARDS, L. A. Diagnosis and improvement of saline and alkali soils. Washington: U. S. Department of Agriculture, 1954. 160 p. (USDA, Agriculture Handbook, $60)$.
RODRIGUES, L. N.; NERY, A. R.; FERNANDES, P. D.; BELTRÃO, N. E. M.; GHEYI, H. R. Crescimento e produção de bagas da mamoneira irrigada com água residuária doméstica. Revista Brasileira de Engenharia Agricola e Ambiental, Campina Grande, v. 13, p. 825835, 2009. Suplemento.

SANTOS, B. dos; FERREIRA, P. A.; OLIVEIRA, F. G. de; BATISTA, R. O.; COSTA, A. C.; CANO, M. A. O. Produção e parâmetros fisiológicos do amendoim em função do estresse salino. Revista Idesia, Arica, v. 30, n. 2, p. 69-74, 2012.

SANTOS, J. B. dos; SANTOS, D. B. dos; AZEVEDO, C. A. V. de; REBEQUI, A. M.; CAVALCANTE, L. F.; CAVALCANTE, I. H. L. Comportamento morfofisiológico da mamoneira BRS Energia submetida à irrigação com água salina. Revista Brasileira de Engenharia Agrícola e Ambiental, Campina Grande, v. 17, n. 2, p. 145-1522, 2013.

SEVERINO, L. S.; VALE, L. S.; CARDOSO, G. D.; BELTRÃO, N. E. de M.; SANTOS, J. W. dos. Método para determinação da área foliar da mamoneira. Campina Grande: Embrapa-CNPA, 2005. 20 p. (Boletim de Pesquisa e Desenvolvimento, 55).

SILVA, E. F. da; ASSIS JÚNIOR, R. N. de; SOUSA, J. I. G. Efeito da qualidade da água de irrigação sobre atributos hídricos de um Neossolo. Revista Brasileira de Ciência do Solo, Viçosa, v. 29, n. 3, p. 389-396, 2005.

SILVA JÚNIOR, L. G. A.; GHEYI, H. R.; MEDEIROS, J. F. Composição química de água do cristalino do Nordeste Brasileiro. Revista Brasileira de Engenharia Agrícola e Ambiental, Campina Grande, v. 3, n. 1, p. 1117, 1999.

SILVA, S. M. S.; GHEYI, H. R.; BELTRÃO, N. E. de M.; SANTOS, J. W. dos; SOARES, F. A. L. Dotações hídricas em densidades de plantas na cultura da mamoneira cv. BRS Energia. Revista Brasileira de Ciências Agrárias, Recife, v. 4, n. 3, p. 338-348, 2009.

SILVA, T. R. B. da; LEITE, V. E.; SILVA, A. R. B. da; VIANA, L. H. Adubação nitrogenada em cobertura na cultura da mamona em plantio direto. Pesquisa Agropecuária Brasileira, Brasília, v. 42, n. 9, p. 13571359, 2007.

SOARES, L.A.A.; NOBRE, R. G.; GHEYI, H. R.; LIMA, G. S.; SILVA, A. O.; SOARES, S. S. Componentes de crescimento da mamoneira cultivada com águas salinas e doses de nitrogênio. Irriga, Botucatu, v. 1, p. 40-54, 2012. Edição Especial.

VIEIRA, R. D.; CARVALHO, N. M. Teste de vigor em sementes. Jaboticabal: FUNEP/UNESP-FCAVJ, 1994. $164 \mathrm{p}$. 